Revista de Economia Política, vol. 32, no 1 (126), pp. 87-108, janeiro-março/2012

\title{
Karl Popper versus Theodor Adorno: lições de um confronto histórico
}

ANGELA GANEM*

Karl Popper versus Theodor Adorno: Lessons from a historical confrontation. In 1961, during the Congress of the German Society of Sociology, two great theoretical references of the XX century faced in a historical debate about the logic of the social sciences. In addition to methodological issues strict sense, the confrontation became known as a debate between positivism and dialectic. The article first deals with the theoretical trajectories of Popper and Adorno and the relation of their theories with their political and ideological certainties. On one hand, the trajectory of the Popperian epistemology is examined, its contributions and vigorous attacks on Marx in what he called "poverty of historicism" and false predictive Marxist world, and, on the other hand, the role of Adorno in the Frankfurt School, his criticism of totalitarianism and the defense of a critical emancipatory reason. The article also deals with the confrontation itself, the exposure of Popper's twenty-seven theses that culminate with the situation logic and the method of the economy as exemplary for the social sciences and Adorno's critical perspective of sociology and society as non-separable objects. In conclusion we show how the articulation of theory with the weltanschauung of each author helps to clarify the terms of the debate and how the confrontation contributed unequivocally to the dynamics of scientific progress and for the critical history of the ideas.

Keywords: Popper and Adorno's debate; dialects; positivism; popperian's method. JEL Classification: B40.

\section{INTRODUÇÃO}

Em 1961, no Congresso da Sociedade de Sociologia Alemã, duas grandes referências teóricas do século XX enfrentaram-se num debate histórico em torno da lógica das ciências sociais. Além de questões metodológicas stricto sensu, o con-

\footnotetext{
* Professora visitante do Instituto de Economia da Universidade Federal do Rio de Janeiro. E-mail: aganem@terra.com.br. Submetido: 8/outubro/2009; Aprovado: 18/junho/2010.
} 
fronto ficou conhecido como o debate entre o positivismo e a dialética. O enfrentamento entre Popper e Adorno, o autor consagrado como o maior epistemólogo do século XX e um dos mais influentes autores da Escola de Frankfurt, guarda uma grande distância da possibilidade da boa conversação de MacCloskey. Entretanto, é exatamente na reafirmação da absoluta impossibilidade de convergência, de consenso, que reside o grande interesse desse debate.

O século XX foi rico em debates polarizados, em confrontos teóricos, políticos e ideológicos, reflexo, entre muitas outras ocorrências, da instigante e problemática experiência do socialismo real e do horror irracional do holocausto. Do ponto de vista filosófico, severas críticas às limitações e aos descaminhos do projeto emancipador iluminista partiam das mais variadas vertentes. É nesse contexto que o artigo se move. $\mathrm{Na}$ primeira seção, pretende-se revelar quem são os dois autores/ atores desse debate, suas trajetórias teóricas e a relação que suas teorias guardam com suas convicções político-ideológicas. Para tanto, examinaremos a trajetória epistemológica popperiana, suas contribuições, bem como as críticas contundentes que fez a Marx, identificadas na "miséria do historicismo" e no que denominou de falso mundo profético marxista. Em seguida, examinaremos o papel de Adorno na Escola de Frankfurt, suas críticas ao totalitarismo e sua defesa de uma razão crítica emancipatória. A segunda seção trata do debate em si. De um lado, situam-se as 27 teses de Popper, que culminam com a lógica situacional e o método da economia como exemplar para as ciências sociais. De outro, a perspectiva crítica da sociologia e da sociedade como objetos indissociáveis para Adorno. Finalmente, nas conclusões, mostramos como a articulação da teoria com a visão de mundo de cada autor é um importante elemento esclarecedor dos termos do debate. A maior lição que retiramos desse episódio é que o confronto, o debate corajoso das ideias, para além de deixar um lastro de interesse pelas obras e pela história dos autores, contribuiu de forma inequívoca para a dinâmica do progresso científico e para a história crítica das ideias.

\section{OS DOIS ATORES E SUAS TRAJETÓRIAS NO CONTURBADO SÉCULO XX}

O século em que viveram nossos dois atores, Karl Popper e Theodor Adorno, foi marcado pelo desencantamento das possibilidades da razão humana na construção de um mundo novo, cujas causas mais contundentes foram o holocausto e o totalitarismo stalinista. Vozes democráticas dissonantes marcaram sua posição contra uma razão totalitária, entre elas a de Hannah Arendt, uma filósofa sensível às agruras do século XX e que não passou ao largo do desastre político produzido pelo totalitarismo, fosse ele fascista ou stalinista, retirando dele lições e consequências que marcaram profundamente a sua teoria. De nada valeram as nuanças e defesas de Marx contidas em suas obras, tampouco a sua crítica à degradação cultural das sociedades capitalistas ou a posição clara que assumiu com relação a 
uma ação política emancipatória. Arendt pagou um preço alto por ter criticado o stalinismo e a ideia de uma ordem socialista fruto de uma razão fabricada.

Dentro da filiação marxista, a Escola de Frankfurt conseguiu construir uma visão crítica da crise teórica e política do século XX consolidando a Teoria Crítica, termo que acabou designando a maior contribuição teórica da Escola. Adorno, um dos seus baluartes, situa-se entre os grandes autores que sustentaram o revigoramento do marxismo na Alemanha, munido de novas perspectivas teóricas e afinado com a discussão imposta pelos rumos do capitalismo no século XX. Construiu uma arguta crítica às expressões contemporâneas do totalitarismo, além de ter percebido as novas formas de dominação e de resistência. Constatou a existência de uma consciência manipulada por uma indústria cultural nociva e observou que a arte e a filosofia poderiam ser antídotos diante de uma experiência humana destituída de sentido.

Numa posição diametralmente oposta, dois autores de peso definiram-se como intelectuais discordantes do socialismo como projeto de sociedade - Friedrich A. Hayek, um dos mais importantes teóricos e ideólogos do neoliberalismo, e Karl Popper, a maior referência entre os epistemólogos do século XX. Ambos foram duros com a ideia de um fim da história associada ao profético mundo socialista marxista. Guardadas as diferenças de método, a Miséria do historicismo de 1944 e A sociedade aberta e seus inimigos de 1945, ambos de Popper, e o Caminho da servidão, de Hayek, publicado originalmente em 1946, têm o mesmo alvo: desmontar cientificamente o argumento da possibilidade de uma leitura da história e derrubar a visão profética do socialismo decorrente de supostas leis imanentes. No lugar do socialismo, temos a apologia do mercado para Hayek e, em Popper, a crença na eficiência de reformas institucionais. A repaginação dessa perspectiva expressou-se na visão extremada de Hayek, uma forma caricaturada da ideia de inexorabilidade, desta feita do mercado. Este, com suas leis imanentes (as regras necessárias da concorrência), determinaria um processo sem sujeito que culminaria na democracia liberal, a face política da vitória da lógica do mercado e da globalização.

$\mathrm{Na}$ década de 1960, trinta anos antes da ascensão do discurso do mercado assentado na inexorabilidade, debatiam-se nos círculos acadêmicos teorias e métodos que dessem conta da lógica das ciências sociais. Com perspectivas diferentes, os dois autores aqui tratados confrontaram-se num debate histórico. Para entender as nuanças teóricas de ambos e os termos do debate, voltaremos no tempo da história de nossos personagens centrais e analisaremos suas trajetórias no conturbado século XX.

\section{Karl Popper: trajetória teórica e visão de mundo}

É interessante a trajetória teórica de Popper entre a primeira publicação da Lógica da descoberta científica, em 1934, publicada em inglês em 1959 (quando adquire notoriedade), e a Lógica das ciências sociais de 1961, no qual estão as suas 27 teses e a apresentação do "método das ciências sociais" ou "método da análise 
situacional". É possível identificar quatro questões que percorrem aquela trajetória e que fornecem boas pistas para o entendimento do autor: a) a novidade do método falibilista aplicado às chamadas ciências experimentais (sem distinção); b) as diversas tentativas em toda a sua obra de marcar uma posição antipositivista; c) uma perspectiva teórico-ideológica crítica ao historicismo (leia-se marxismo) e ao psicologismo e, finalmente, d) o método da lógica situacional que revela o esforço teórico de levar em conta a especificidade das ciências sociais e que pode ser lido como o resultado desse longo percurso teórico e crítico.

Popper se considera um racionalista crítico. Mas a que racionalismo ele dirige a sua crítica? Antes de tudo, Popper identifica-se com Heidegger na crítica ao homem moderno que supostamente vê a verdade. $\mathrm{O}$ homem da revolução científica moderna pretende descobrir a verdade e projetá-la para a eternidade, tal qual o demônio do matemático Laplace. Para ele é preciso superar pela crítica o indutivismo baconiano ingênuo (a ideia de uma ciência ditada pelo império das observações) e o desvario de uma razão onipotente que descobre a verdade por meio do raciocínio de dedutivo. Popper considera que, através de sua razão crítica, estaria superando Descartes, Bacon e ainda a tentativa de síntese kantiana nos juízos sintéticos a priori. Consoante com o seu tempo, em que a razão moderna sofre abalos sísmicos, Popper, mediante seu método dedutivo, acena com a provisoriedade do conhecimento, posto que limitado por nossa ignorância latente. Seu compromisso é com proposições constantemente renovadas por novas conjecturas, frutos da correção constante de erros. Tateando entre erros e acertos, o critério que dá substância ao seu método é o da falseabilidade, ou o confronto rigoroso e impiedoso das teorias com a observação e a experiência. Em última instância, trata-se da eliminação das teorias incapazes de resistir aos testes e da sua substituição por outras conjecturas especulativas mais promissoras. O critério de falseabilidade, termômetro do método, define o que é objeto significativo para as ciências experimentais e que nos permite deduzir, com o auxílio de condições iniciais, os efeitos que se pretende explicar. Mas esse critério é demarcatório, pois separa as ciências empíricas, a matemática e a lógica dos sistemas metafísicos (Popper, 1989 [1959]).

Entretanto, Popper alerta que seu objetivo não é o de provocar a derrocada da Metafísica, como pretendem os positivistas, desqualificando-a e jogando-a no campo da não significação, da conversa vazia. Ao contrário, ele considera que esse movimento asséptico dos positivistas, cientificamente neutro e expurgado de todos os valores, fez com que se aprisionasse a própria ciência no reino da metafísica. Nas suas palavras: Os positivistas, ao tentarem aniquilar com a metafísica, aniquilam com a ciência natural e, em vez de afastar a metafísica das ciências empíricas, levam à invasão do reino científico da metafísica (Popper, 1989 [1959]).

É marcante a preocupação de Popper em se distanciar do positivismo. Se conseguiu ou não o seu intento é algo absolutamente controverso, sobretudo, se analisarmos à luz da perspectiva dialética, como Adorno o fez. Entretanto mesmo Adorno sugere que a teoria de Popper se diferencia dos positivistas tradicionais. Ele afirma: A teoria de Popper é mais ágil do que o positivismo usual. Ela não insiste tão irrefletidamente na neutralidade dos valores (Adorno,1975 [1974]). Ainda que 
se identifique Popper com o positivismo, não podemos desconsiderar as nuanças de sua teoria, sob pena de empobrecer o debate e dificultar a compreensão do autor. Voltaremos a esse ponto quando do embate entre ele e Adorno.

Popper, além disso, se posiciona contra o pensamento dogmático. Este pode ser entendido pela perseguição de uma verdade absoluta ditada pela observação ou pela lógica (positivismo), mas também pela preocupação da descoberta de leis imanentes e inexoráveis da história (historicismo). O antídoto de que Popper se utiliza contra a onipotência da razão é o relativismo, ou a ideia de que uma teoria jamais atinge a verdade, mesmo que ela tenha superado vitoriosamente os testes rigorosos. Para ele, o máximo que se pode afirmar é que a teoria atual é superior às que a precederam, ou a melhor disponível. Ela jamais será a verdadeira. O pensamento dogmático ele o identifica, sobretudo, no marxismo, alvo de suas mais severas críticas, mas também de contundentes elogios. Uma relação de distanciamento e de admiração teórica. É disso que trataremos a seguir.

Dez anos após a Lógica da descoberta científica, de 1934, Popper publica duas obras que fizeram sucesso e o alçaram ao palco dos debates mais importantes do século XX. Esses debates tratavam das agruras do socialismo real e das dificuldades teóricas do socialismo científico, bem como da abertura de possibilidades de reformas pelo próprio capitalismo. A Miséria do historicismo, de 1944, (Popper 1956, [1944]) e A sociedade aberta e seus inimigos, de 1945 (Popper, 1979), tinham como objetivo, como já adiantamos, desmontar a possibilidade de encontrar leis gerais unívocas para a história, desacreditar a profecia socialista e substituir a utopia socialista por um reformismo, ideal que ele considerara mais modesto e mais viável numa sociedade democrática liberal.

Na Miséria do historicismo (1956 [1944]), Popper define o objeto de sua análise como uma crítica ao historicismo, identificado na missão de estabelecer leis, modelos, ritmos ou tendências gerais dos desenvolvimentos da história com objetivo de prever o seu fim. O principal historicista para Popper é Marx e o fim escatológico que ele propala é o de uma sociedade sem classes, socialista. Contra essa tese, Popper advoga três posições explicitadas de antemão e que desenvolve em argumentos ao longo do livro: 1) é impossível predizer o curso futuro da história e as ciências sociais não têm a missão de estabelecer leis do desenvolvimento da história; 2) o método das ciências sociais não é tão distante das ciências naturais, ao contrário, existe uma unidade metodológica; 3) é importante substituir o ideal utópico do plano da reconstrução socialista por um ideal mais modesto expresso num reformismo fragmentário. ${ }^{1}$

Nesse texto, Popper discorre sobre os pontos controversos e críticos, tanto das teses naturalistas como das chamadas teses antinaturalistas do historicismo. Ele

\footnotetext{
${ }^{1}$ Popper foi socialista quando jovem e, em 1919, se juntou aos comunistas nas contestações da esquerda austríaca no conturbado pós-guerra. Entretanto, diante da morte de alguns companheiros, tornou-se crítico do comunismo, sobretudo da ideia de que é necessário usar meios violentos para alcançar os fins (Hacohen, 2000).
} 
ataca a crença central do historicismo de que a função das ciências sociais seria desvendar a lei da evolução da sociedade e predizer seu futuro. Contra uma ordem invariável na evolução biológica ou sociológica, Popper afirma a ideia de um processo que se efetua de acordo com leis causais em que elas mesmas e/ou as suas consequências devem ser testadas. O método hipotético da prova, seu método aplicável a todas as ciências experimentais, oferece explicações causais dedutivas e ainda a possibilidade de testá-las. Nisso residiria a sua novidade teórica, seu racionalismo crítico e a diferença entre o seu método e o de Marx - uma abertura para múltiplas possibilidades, e não algo predeterminado e previsível (Popper, 1956 [1944]).

Embora ele tenha explorado a crítica ao materialismo histórico na Miséria será na Sociedade aberta e seus inimigos publicada originalmente em 1945 (Popper, 1979) que seus estudos se aprofundam, tomam força e consistência, dando lugar não apenas a críticas, como a elogios à contribuição de Marx. Em primeiro lugar ele reconhece a importância e a grandeza da teoria humanista de Marx e afirma textualmente que a contribuição do marxismo foi de tal ordem que retornar às teorias sociais anteriores seria um grande atraso. Ele afirma que Marx foi um dos melhores adversários da hipocrisia e do farisaísmo e que consagrou todas as suas forças a forjar armas que ele considerava científicas destinadas a melhorar a sorte dos oprimidos. Em outro trecho afirma que contrariamente aos hegelianos de direita, Marx se esforçou para resolver pelos métodos racionais os problemas mais agudos de seu tempo. Que ele não tenha conseguido não lhe tira o mérito. A ciência só progride graças 'a experiência [...] Apesar de todas essas qualidades ele foi um falso profeta. E finaliza, afirmando que não somente as profecias relacionadas ao curso da história não foram realizadas como ele induziu ao erro aqueles que acreditaram que a profecia histórica era um método científico que permitia resolver os problemas sociais. (Tradução livre da edição francesa, Popper, 1979).

Analisando o método de Marx, Popper desenvolve seu argumento crítico central que é atacar o determinismo sociológico e defender a ideia de uma sociedade aberta às reformas. Quando a sociedade pensa que descobriu a pista da lei natural que preside o seu movimento, ela não pode superar de um salto nem abolir as fases do seu desenvolvimento natural, nos diz Popper. Neste quadro de previsibilidade não há engenharia social que possa reformar ou corrigir ou, dito em outros termos, melhorar a sociedade pela razão ou pelas instituições. É interessante como esta perspectiva se diferencia da de Hayek, seu conterrâneo, que considera Marx um racional-construtivista que concebia a ordem socialista como fruto do plano ou do desígnio de uma classe operária consciente. ${ }^{2}$ São dignas de nota as diferenças teórico-políticas entre Hayek e Popper, ambos severos críticos do que chamaram de

\footnotetext{
${ }^{2}$ Hayek constrói sua crítica a Marx concentrando naquilo que seria o pecado capital da razão: uma razão onipotente oriunda da classe operária que transformaria a sociedade numa máquina racional, uma razão que é capaz de digerir a sua própria complexidade e que constrói pela deliberação de seus sujeitos sociais um devir socialista (Hayek, 1985).
} 
profecia marxista. Popper, ao contrário de Hayek, acredita na engenharia social, na capacidade de reformar as instituições e com isso aperfeiçoar a democracia liberal. Já Hayek, um fundamentalista do mercado, é avesso a toda e qualquer intervenção, a qualquer engenharia social.

Para Popper, um dos problemas do socialismo científico é o de não ser uma tecnologia social. Sua tarefa seria, nos seus termos, a de anunciar messianicamente a chegada do socialismo e de acelerá-lo, advertindo aos homens o papel que terão de jogar no desenvolvimento da história. Os personagens seriam para Popper marionetes movidos pelos fios da economia, por forças históricas. Um dia, ele afirma de forma irônica, essas marionetes destruirão o sistema e nós viveremos no reino da liberdade. Consoante, portanto, com o materialismo histórico, as classes sociais desempenhariam um papel central, pois a história de toda sociedade é a história de luta de classes. No materialismo histórico é o sistema que nos obriga a agir de acordo com os interesses de classe, crendo que são nossos interesses. Nesse quadro, afirma Popper, levantando o ponto que ele considera crítico, toda engenharia social é impossível, toda tecnologia social, inútil. Uma outra crítica é que a chave da história e da história das ideias se encontra na relação do homem com o mundo material que o cerca (fundamento da teoria de classes). Isto faria toda a diferença, pois seria na evolução da realidade econômica e na sua capacidade de produzir uma modificação real que residiriam as potencialidades da revolução. Esta começaria quando as forças produtivas materiais da sociedade entrassem em colisão com as relações de produção. Ora, isso definiria para Popper um viés economicista da teoria de Marx, que absolutiza a economia e não confere às ideias um papel determinante, uma crítica que apenas engrossa o que, no interior do próprio marxismo, já tinha sido apontado como uma leitura empobrecedora e adulterada da teoria de Marx. Nada de novo.

Na Sociedade aberta, de 1945, observamos em Popper o primeiro esforço para romper com a ideia de um método unívoco para as ciências experimentais e os indícios de querer trabalhar a especificidade das ciências sociais, o que só vai adquirir seus contornos definitivos na Lógica das ciências sociais, em 1961 (Popper, 1978). É interessante observar como a crítica ao psicologismo e a perspectiva de uma autonomia para a sociologia, partes integrantes de sua teoria, têm pontos de confluência com a crítica marxista, seu alvo preferido.

Popper revela simpatia pelo antipsicologismo de Marx, definido pela máxima não é a consciência dos homens que determina a sua existência, mas é a sua existência social que determina a sua consciência. A autonomia da sociologia, conforme ele a define, se dá porque os atos humanos não podem ser explicados por motivos e desejos psíquicos e dependem, para a sua real compreensão, da consideração das condições gerais, do entorno social, das instituições. Popper concorda com Marx na crítica que ele faz aos psicologistas, de que a instituição mercado seria determinada pela psicologia do homem econômico e seu interesse pessoal na perseguição da riqueza. Além de equivocada, a teoria alimentaria a tese do complô. Mas embora Popper sublinhe que os aspectos psicológicos têm um papel secundá- 
rio em relação à lógica da situação ${ }^{3}$ e que a sociologia tem a sua autonomia e importância para a compreensão de uma lógica dos fenômenos sociais, ele fez questão de marcar uma diferença importante com relação ao método marxista. Seu método não é holista, mas individualista e baseado no princípio da racionalidade. ${ }^{4}$ Examinaremos oportunamente esse delicado e importante ponto no confronto entre ele e Adorno.

Em várias outras passagens elogiosas a Marx, Popper afirma que ele faz uma boa leitura da lógica da situação de classe para o capitalismo sem entraves do século XIX. ${ }^{5}$ Popper vai utilizar a mesma expressão lógica da situação (sem a palavra classe) para desenvolver mais adiante suas teses sobre o método das ciências sociais e da economia, em particular, rompendo com o ideal de uma ciência unificada. Popper reconhece o mérito de Marx ao ter explicado o fenômeno da exploração e ter demonstrado a importância social dos ciclos econômicos, complexos e mal conhecidos até então. Entretanto, o erro da tese marxista apontado por Popper na Miséria, como já assinalamos, é o determinismo ditado pela lei do antagonismo da luta de classes sociais e a profecia da revolução (agora mais qualificada pelas referências a $O$ capital), de que a situação se agravaria através da lei do empobrecimento. A tendência à queda na taxa de lucro ameaça de ruína os empresários que se defendem aumentando a jornada de trabalho. Essa constatação de Marx soa correta para Popper, mas ele ressalta que na história do capitalismo a situação dos operários, ao invés de piorar, melhorou graças às negociações. Popper rebate teoricamente as teses marxistas e advoga que para o campo político-normativo o melhor é a negociação para a obtenção de melhoras progressivas do capitalismo, o que significa uma diminuição do antagonismo entre as classes sociais.

No plano epistemológico, Popper construirá o método da análise situacional para as ciências sociais, elegendo a economia como modelo exemplar. Veremos que esse método pode ser lido como uma correção crítica ao método dedutivo, em última análise, um reformismo epistemológico. $\mathrm{O}$ método, suas potencialidades e limitações, e ainda a natureza do racionalismo crítico popperiano serão examinados na apresentação e nos comentários ao debate. A seguir, passemos à trajetória teórica do nosso segundo autor-ator, Theodor Adorno.

\footnotetext{
${ }^{3}$ Num artigo de 1945, intitulado A autonomia da sociologia, Popper esboça o princípio da racionalidade no quadro de uma "lógica da situação", afirmando que o método da análise econômica não está baseado em nenhum suposto psicológico que se refira à racionalidade ou outro fator da natureza humana. Ao contrário, quando nos referimos à conduta racional ou irracional, nos referimos a uma lógica que está conforme com uma lógica de uma situação particular. Weber já dizia que o racional existe depois das normas do que é considerado racional (Popper, 1995).

${ }^{4}$ Sobre o princípio da racionalidade em Popper, consultar El Principio de Racionalidad, em Miller, D. (org.) Popper Escritos Selectos. México: Fondo de Cultura Económica, 1995.

${ }^{5}$ Popper afirma textualmente que [...] a maneira com que Marx procurou explicar o funcionamento das instituições do sistema industrial pela lógica da situação de classe me parece admirável pelo menos no que concerne ao capitalismo sem entrave do século passado (Popper, 1979).
} 


\section{Theodor Adorno e a Escola de Frankfurt}

A trajetória teórica e biográfica do filósofo Theodor Wiesengrund-Adorno está intimamente ligada ao grupo mais importante de pensadores do Instituto de Pesquisa Sociais de Frankfurt, fundado em 1924 e conhecido como Escola de Frankfurt, de tradição marxista. Entre eles, além de Adorno, cabe mencionar Walter Benjamin, Max Horkheimer e mais tarde o herdeiro da tradição, Jürgen Habermas. Embora outros nomes tenham se destacado, como o de Herbert Marcuse, por exemplo, é possível identificar uma unidade teórica entre aqueles quatro autores. Essa unidade se dá pela chamada "Teoria Crítica”, em que a razão só pode ser defendida pela via de uma crítica a ela mesma. Podemos afirmar que os trabalhos desse grupo tratam de uma reflexão crítica sobre os principais aspectos do capitalismo, da sociedade e da cultura do século XX, no quadro de experiências do nazismo e do stalinismo. Por suas posições, com a ascensão do nacional-socialismo na Alemanha, a Escola foi obrigada a transferir-se para Genebra em 1933, em seguida para Paris e, finalmente, para Nova York. Somente em 1950, já no pós-guerra, é que os principais integrantes puderam regressar à Alemanha e reorganizá-la.

Adorno nasceu em 1903 e morreu em 1969, em Frankfurt. Na década de 1930, refugiado na Inglaterra, lecionou na Universidade de Oxford. Por essa época, escreveu vários ensaios críticos sobre o caráter social e potencialmente transformador da música, da qual era um estudioso e profundo conhecedor. No fim da década, mudou-se para os Estados Unidos, onde escreveu com Horkheimer a obra seminal Dialética do esclarecimento, publicada em 1947. Em 1950 regressou à Alemanha para reorganizar a Escola em companhia de Horkheimer. Escreveu inúmeros trabalhos sobre os mais variados assuntos culturais e filosóficos. Dentre eles um importante trabalho em que apresenta a sua compreensão sobre o método dialético: a Dialética negativa, em 1966.

Tanto na Dialética do esclarecimento como na Dialética negativa, Adorno dedicou-se à dialética, entendendo-a como um método crítico capaz de enfrentar os inúmeros desafios teóricos ditados pela hegemonia do pensamento positivista e pelo idealismo hegeliano. Somaram-se a essas questões, outras, concernentes à reprodução ideológica do capitalismo contemporâneo e aquelas ligadas às formas totalitárias stalinistas e nazistas. A dialética, para Adorno, teria a incumbência de ser uma reflexão filosófica sobre aquilo de que os conceitos e análises não dão conta. Ela deveria se constituir num pensar ousado sobre exatamente o que lhe escapa, aliás a única saída para se pensar filosoficamente.

Na Dialética do esclarecimento (1985 [1944]), os autores Adorno e Horkheimer avisam que o positivismo assumiu a magistratura de uma razão esclarecida em que nada supostamente lhe escaparia. Os fenômenos são traduzidos em um sistema de vários signos interligados e o pensamento se transforma em instrumento matemático. A lógica formal na sua expressão máxima, através da matemática, fornece o esquema de calculabilidade do mundo; o procedimento matemático torna-se o ritual do pensamento, instaurando-se como necessário e objetivo. Nesse quadro, o desconhecido, o opaco, ou ainda, o inexplicável, tornam-se incógnitas de equações 
no quadro de teoremas matemáticos. Entretanto, o que aparece como triunfo de uma racionalidade objetiva e a submissão de todo ente ao formalismo lógico tem por preço a subordinação obediente da razão ao imediatamente dado. No quadro do positivismo e da razão esclarecida, o factual tem a última palavra, o conhecimento se restringe à repetição e o pensamento transforma-se em tautologia (Adorno e Horkheimer, 1985 [1944]).

Ao identificar o mundo matematizado com a verdade, o pensamento positivista acredita estar a salvo do retorno do mítico ou do destituído de significado. Mas o esclarecimento na sua obsessão matematizante é a própria radicalização da angústia mítica. Aprisionadas pelo mito, tanto a ciência como a técnica refletem o desencanto das esperanças de que o iluminismo instauraria o poder do homem sobre elas, libertando-o do medo, da magia e do mito. Caminhando por essa área de técnicas reificadas, Adorno cunha o nome de indústria cultural à produção, comercialização e exploração de bens culturais próprias das técnicas de reprodução (a produção em série e a homogeneização). Essas técnicas têm sua racionalidade ditada pela racionalidade instrumental dominante. Tendo-se em vista o papel determinante da indústria cultural como veículo da ideologia dominante, as possibilidades de libertação através da arte e do lazer estão condenadas ao fracasso. Para Adorno, a música, tal como a arte em geral e as grandes filosofias, faz falar o que a dominação e a ideologia escondem sob a couraça da identidade ou suprimem como irrelevante e nocivo. Sua teoria crítica poderia ser considerada uma teoria estética, tal o papel da arte e da filosofia como antídotos para o racionalismo positivista e pseudocientífico que violentam o objeto, consumindo-o dentro de um esquema conceitual reificado (Adorno e Horkheimer, 1985 [1944]).

Na obra Dialética negativa (2009 [1969]), Adorno elege como seu maior alvo crítico o idealismo da filosofia dialética hegeliana na sua peculiaridade de uma lógica da identidade e na subordinação do indivíduo à totalidade social, às custas do sacrifício de sua singularidade. Trata-se de uma crítica à dialética conciliatória de herança lucaksiana e um aviso para uma releitura da perspectiva de totalidade, pois esta pode dar lugar ao totalitarismo de um sistema em que vige a lei da unidade e, portanto, da eliminação do diverso. A dialética negativa significa para Adorno o respeito à negação, às contradições, ao diferente, ao dissonante, ao não idêntico, enfim, o respeito às contradições do objeto. Isso significa considerar o que permanece fora do conceito, o que lhe escapa, o que aponta a sua insuficiência. Adorno diz não ao idealismo em que o sujeito é o portador da verdade do objeto e em que a desmesura da razão faz imaginar que os conceitos podem esgotar o real e ainda apresentar soluções para os seus problemas. Para ele, a experiência é o encontro com a alteridade e não uma projeção do sujeito no outro.

Para Adorno deve-se pensar o objeto mesmo quando ele não segue as regras do pensamento, mesmo quando não se sabe se é possível compreendê-lo por inteiro. Nesse sentido, a dialética negativa pensa onde seus opositores se detêm. Fortalecendo seu argumento, Adorno afirma que as catástrofes revelam a inadequação dos conceitos. A impossibilidade de representar a dor mostra que a saída não é uma dialética conciliatória ou idealista, mas uma dialética que eleve a dor ao conceito. Ela 
(a dor) seria o limite em que explode o conceito, a própria essência da dialética negativa. Ela estaria personificada na dor dos fracos, dos impotentes, dos perseguidos, desses que a história marginalizou e aniquilou. Auschwitz seria o melhor signo para a dialética negativa. Segundo Adorno, deve-se trazer à luz da consciência as mutilações, as divisões e as degradações, bem como tudo que hoje é oprimido, impotente e não funcional, num mundo regido pelo princípio da equivalência na troca e na identidade. Só nesse acúmulo de dor que nos projeta para um tempo que não é o nosso é que poderemos entrever o desaparecimento da totalidade antagônica. Então terá fim a pré-história da humanidade (Adorno, 2009 [1969]; Bodei, 2000).

Entretanto, esse fim não significa que seria ditado por leis inexoráveis conduzidas pelo sujeito consciente da classe operária. Iconoclasta, Adorno considera que a classe operária está limitada, de um lado, por um socialismo burocrático e, de outro, por um capitalismo que reproduz a sua dominação cultural e ideológica de forma eficiente e devastadora. Para o autor, as minorias excluídas (aquelas que carregam a força e a dor) são a dinâmica viva da sociedade e de suas possibilidades emancipatórias.

No texto intitulado Introdução à controvérsia sobre o positivismo na sociologia alemã, publicado em 1974, cinco anos após a morte de Adorno, em 1969 (Adorno, 1975 [1974]), ele revela de forma clara a distância teórica que separa epistêmica e ontologicamente a dialética do método positivista e esclarece questões de fundo que nortearam suas posições no confronto de 1961. Nesse texto, Adorno apresenta-nos a dialética como um método intrinsecamente dependente de seu objeto, o que impede a sua apresentação como um para-si tal qual no sistema dedutivo. A dialética, nos diz o autor, não obedece ao critério de definição, critica-o. Ela não possui um cânone que a regula e, ainda assim, ela tem a sua razão de ser. Já o positivismo tem como prioridade a lógica formal, uma concepção cientificista, em que o pensamento persegue a mais extrema objetividade, purificada de todas as projeções subjetivas. Uma de suas flagrantes contradições é o seu enredamento na particularidade de uma razão instrumental subjetiva. Para Adorno, a ideia de filosofia de Wittgenstein, por exemplo, para a qual os pensamentos vagos e obscuros devem tornar-se claros e delimitados, remete a Comte.

Com relação à objetividade científica e à expulsão de valores, Adorno nos adverte que um conhecimento que é tão livre de preconceitos como pretende ser o positivismo teria que contar com coisas que são tudo, menos claras. O mundo é em si tão ambíguo que não é suficiente como critério de sentido. Quem não percebe isso não pode ascender a um autêntico conceito de sociedade. A sociedade, este objeto complexo, é inteligível porque comporta atos subjetivos em que o sujeito reconhece a si mesmo e é, ao mesmo tempo, ininteligível, porque a racionalidade objetiva da troca afasta-se cada vez mais do modelo da razão lógica (Adorno, 1975 [1974]).

Foi o formalismo, a instrumentalização e a virtual matematização como critérios únicos de cientificidade que completaram a liquidação da diferença qualitativa da sociologia em relação a outras ciências. O ideal de um sistema dedutivo que não deixa nada de fora é a lógica que fornece o ideal de ciência unificada. Nesse ponto, ele concorda com Habermas, quando afirma que não são as teses do formalismo 
sociológico de Simmel que são falsas em si, mas sim os atos do pensamento que as arrancam da empiria e, posteriormente, lhes conferem conteúdo ilustrativo. No interior da sociedade coisificada nada tem chance de sobreviver que não seja coisificado. A objetividade da estrutura que para os positivistas é uma relíquia mitológica, para a dialética é o a priori da razão subjetiva cognoscente (Adorno, 1975 [1974]).

Entretanto, a elegância do refinamento matemático não dissipa a suspeita de que ocorre uma conversão da ciência em técnica, minando o seu próprio conceito. Entre perplexo e provocativo, Adorno pergunta como pode Carnap, um dos positivistas mais radicais, denominar de "afortunado acaso" a constatação de que as leis da lógica e da matemática pura se aplicam à realidade? "Acaso”, lembra ele, não deixa de ser um conceito mítico.

Outro ponto incontornável que marca a diferença substantiva entre os dois métodos é o conceito de totalidade. Para Adorno esta não deve ser entendida como uma categoria afirmativa, mas crítica, pois ela não é fática como são os fenômenos singulares. O caráter abstrato do valor de troca está vinculado a priori à denominação de universal sobre o particular. Ele não é socialmente neutro, como simula a logicidade do processo de redução a singularidades, tal como o tempo de trabalho social médio. Através da redução dos homens a portadores de mercadorias realiza-se a dominação dos homens pelos homens. Todos são obrigados a se submeter à lei abstrata da troca. O cerne da crítica ao positivismo é que ele fecha a experiência de totalidade, se satisfaz com os destroços desprovidos de sentido, sem interpretar e descobrir a verdade. Adorno afirma que é falsa a ideia de que a dialética se ocupa de um global generalizado e que os positivistas se ocupam dos detalhes sólidos. A sociedade é sistema como síntese de um diverso atomizado, sinopse real, mas abstrata de algo não reunido organicamente. O télos do modo dialético de encarar a sociedade é o contrário do global. A dialética, nesse sentido, é mais realista do que o cientificismo com todos os seus critérios de sentido. Apesar da reflexão sobre a totalidade, a dialética não procede a partir do alto, mas trata de dominar teoricamente pelo seu procedimento a relação antinômica do universal e do particular. Toda dialética é dialética da totalidade, um conceito que pretende ser objetivo, aplicável a qualquer constatação singular. Já a teoria positivista é a escolha de categorias gerais no intento de reunir constatações sem contradições num conjunto lógico. O problema é que não há conceitos estruturais superiores. Ao denegrir o conceito de totalidade como retrocesso mitológico e pré-científico o positivismo, em infatigável luta contra a mitologia, mitologiza a própria ciência. Esse ponto permite uma aproximação com a crítica que Popper faz ao positivismo. As nuanças teóricas e as diferentes perspectivas ficarão claras no confronto, assunto ao qual passaremos a seguir.

\section{O CONFRONTO ENTRE POPPER E ADORNO}

O debate realizado no Congresso da Sociedade Alemã de Sociologia (1961) iniciou-se com o confronto entre Popper e Adorno. No livro publicado do Con- 
gresso $^{6}$ outros autores participaram, como Hans Albert e Jürgen Habermas. Pela magnitude do tema e pela importância de seus atores no cenário intelectual, a discussão passou a ser conhecida como um debate entre o positivismo e a dialética da teoria crítica. Para a teoria crítica, da Escola de Frankfurt, a racionalidade instrumental presente no positivismo significou a submissão ao formalismo lógico e à obediência ao imediatamente dado. A identificação da postura positivista de Popper estaria, entre outros pontos, na sua observância aos princípios básicos da lógica formal cartesiana para assegurar a cientificidade e a objetividade do pensamento teórico. Já para os positivistas, a teoria crítica permanecia como uma metafísica vazia, destituída de sentido.

\section{As teses de Popper}

As 27 teses de Popper são uma condensação dos principais conceitos e posições teóricas que sustentam o edifício do seu racionalismo crítico (Popper, 1978). As primeiras teses apresentam o foco de tensão essencial da sua perspectiva teórica, localizado no aumento do conhecimento e no discernimento de uma ignorância ilimitada - uma tensão entre saber e não saber, como Popper define $\left(1^{\mathrm{a}}, 2^{\mathrm{a}}\right.$ e $3^{\mathrm{a}}$ teses). Esse foco tem a sua expressão maior nos problemas, ponto de partida da ciência popperiana que, além de se distanciar do indutivismo ingênuo, imprime dinâmica ao desenvolvimento científico marcado por soluções encontradas e novos problemas que surgem ( $4^{a}$ tese). Mas qual a natureza desses problemas? De toda ordem (prática e teórica) desde que tenham audácia e originalidade ( $5^{\mathrm{a}}$ tese). Retomando o método dedutivo da prova dos seus primeiros escritos, Popper afirma que o método para as ciências (indiscriminadamente ciências sociais e ciências naturais) consiste em experimentar possíveis soluções para os problemas. As hipóteses, uma vez submetidas à crítica do critério de falseabilidade, poderão ser descartadas ou aceitas ( $6^{a}$ tese). Nesse ponto, Popper sublinha que é na crítica que reside a objetividade do método científico de ensaios e erros. O erro, ponto sensível do teste, prenuncia um caso de ignorância e confirma a natureza provisória do nosso conhecimento ( $7^{a}$ tese).

Para Popper existem dois mitos a serem combatidos: o indutivismo e o mito da neutralidade científica. Contra o método observacional, Popper fornece como exemplo a antropologia - ciência-chave que aplica esse método pseudocientífico, supostamente descritivo e objetivo $\left(8^{\mathrm{a}}, 9^{\mathrm{a}}\right.$ e $10^{\mathrm{a}}$ teses). Contra a falsa objetividade científica, ele afirma que é um erro achar que esta depende dos cientistas isoladamente. Ela é o resultado social de uma crítica recíproca, da divisão de trabalho entre cientistas, da sua cooperação e da sua competição (12a e $13^{a}$ teses). Embora considere que seja impossível eliminar os interesses do cientista com relação a problemas extracientíficos, sob pena de roubar-lhes a humanidade, e que a ciência

\footnotetext{
${ }^{6}$ As teses do Congresso foram compiladas por Ralph Dahendorf (1973), obra intitulada La disputa del positivismo a la sociologia alemana.
} 
pura é um ideal inalcançável, devemos lutar por esse ideal. O caminho da crítica é aquele que separa os problemas dos valores científicos como verdade, relevância e simplicidade, dos problemas extracientíficos (14 tese). Para marcar a diferença entre seu método científico e o método lógico de tradição cartesiana ele expõe esta como a teoria das deduções lógicas ou das relações de consequência lógica. A lógica dedutiva é a teoria da transmissão da verdade das premissas à conclusão $\left(16^{a}\right.$ e $17^{a}$ teses). Do seu ponto de vista, o que diferencia seu método dedutivo (o racionalismo crítico) da lógica dedutiva da tradição cartesiana seria seu sistema de crítica ( $15^{a}$ tese). Se existem conclusões inaceitáveis, então a afirmação é digna de ser recusada. Uma tentativa de explicação é uma tentativa de solução de um problema científico, mas uma teoria pode ser criticada racionalmente através de suas consequências ( $18^{a}$ e $19^{a}$ teses). Definido o método dedutivo e o papel da crítica dentro dele, o qual chama de método dedutivo da prova, Popper reforça seu ponto de partida inegociável: a verdade como uma aproximação, como a melhor possível. E afirma mais uma vez o quanto é equivocada a pretensão de uma teoria verdadeira. Um enunciado pode ser verdadeiro ou falso, o que ele representa é uma aproximação da verdade (20a tese).

Popper, nessa altura de sua apresentação, retoma a crítica ao indutivismo ingênuo, afirmando que não existe nenhuma ciência puramente observacional, agora por uma outra preocupação, a de apresentar sua lógica situacional, o que fará nas últimas teses. Introduz a questão mostrando que a psicologia (imitação, linguagem, família) pressupõe ideias sociais, o que demonstra ser impossível explicar a sociedade exclusivamente em termos psicológicos. A psicologia não é a base das ciências sociais, o ambiente social é um pressuposto da psicologia. A sociologia é autônoma, isto é, independente da psicologia e não pode ser reduzida à psicologia $\left(23^{\mathrm{a}}\right.$ e $24^{\mathrm{a}}$ teses). Tudo isso para mostrar que o melhor exemplo dentre as ciências sociais é a economia. É na economia que reside o método objetivo nas ciências sociais, ou o método da compreensão objetiva ou, ainda, o método da lógica situacional que pode ser aplicado em todas as ciências sociais. Esse método da análise situacional, alerta Popper, é individualista (um individualismo que leva em conta o ambiente social), mas não é psicologista. O homem motivado autonomamente por seus desejos dá lugar ao homem que persegue alvos condicionados a determinada situação ( $25^{a}$ tese). Sendo as explicações da lógica situacional reconstruções racionais e teóricas, elas são simplificadas, esquematizadas e geralmente falsas. Entretanto, podem ser boas aproximações da verdade e melhores do que outras explicações testáveis. O conceito de aproximação da verdade é indispensável para uma ciência social que usa o método da análise situacional ( $26^{a}$ tese). A lógica situacional admite o mundo físico, o mundo social, outros povos e as instituições sociais, mas as instituições não agem. Ao descartar a ação das instituições reafirma que o que há de concreto são os indivíduos que agem.

Finalmente, Popper afirma que a intranquilidade filosófica e religiosa adviria da ideia socrática de que nada sabemos. Mas isso é apenas uma meia verdade. Podemos superar o niilismo, pois embora não possamos justificar as nossas teorias 
racionalmente, nem mesmo provar que são prováveis, podemos criticá-las racionalmente e com isso distingui-las das piores (Popper, 1978).

\section{A réplica de Adorno}

A apresentação de Adorno caracterizou-se por um conjunto de argumentos críticos à exposição de Popper, ao mesmo tempo em que deixou claras suas próprias posições teóricas (Adorno, 1986). Organizamos, para efeito didático, suas críticas em quinze pontos:

1) a ideia do conhecimento crescente e de uma ignorância ilimitada está insuficientemente explorada em Popper. Além disso, o não conhecimento passageiro não é superável por aquilo que se denomina síntese. O não saber apenas atesta a divergência entre a sociedade como objeto e o método tradicional utilizado por Popper; 2) não pode existir uma explicação unívoca, simplificada ao máximo, matematicamente elegante, porque o objeto sociedade não é unívoco, nem simples; 3) o positivismo é vítima inconsciente de uma contradição interna, porque a sociedade é contraditória (ela é racional e irracional, sistemática e caótica, de natureza cega e mediada pela consciência); 4) Popper é contraditório no desejo de objetividade científica, pois o positivismo deseja uma objetividade extrema, ou seja, purgada de toda projeção subjetiva. Entretanto, Popper não hesita em recorrer a uma razão instrumental subjetiva; 5) a sociedade é um problema e a contradição não deixará de existir pelo simples fato de conhecermos mais, ou porque formulamos o problema de maneira mais clara, ou ainda porque a solução proposta foi verificada ou refutada. A contradição está no objeto; 6) o que existe é uma situação problemática do mundo e não um problema de caráter meramente epistemológico; 7) a preocupação de Popper é formal ao invés de material e emancipatória, como é a dialética. Nessa perspectiva, a sociologia tem que se preocupar com o todo mesmo quando estuda as particularidades; 8) Popper afirma que a qualidade do profissional está na identificação de problemas significativos. Nem sempre é possível um julgamento a priori acerca da relevância dos assuntos; 9) as teorias do conhecimento, tanto de Bacon quanto de Descartes, os chamados métodos indutivo e dedutivo, foram concebidas de cima para baixo. O importante não é uma descrição segundo um método lógico. Nem o método da lógica formal nem o da lógica situacional têm um papel preponderante para o conhecimento. Não é o método que garante a objetividade e a neutralidade da empreitada científica em busca da verdade; 10) para aceitar o conhecimento sociológico como crítico e separar a sociologia das ciências naturais, o conceito de experimento tem que se estender ao pensamento crítico que, saturado pela força da experiência, ultrapassa essa mesma experiência para compreendê-la. O momento especulativo é imprescindível; 11) a sociologia é crítica do objeto. Se a sociologia pretende que seus conceitos sejam verdadeiros, então ela deve ser crítica com relação à sociedade. A crítica é ao objeto, a sociedade capitalista liberal. A sociologia crítica não se reduz apenas a uma autocrítica da disciplina, mas estende a crítica ao próprio objeto da análise e às hipóteses, conceitos e teorias desenvolvidos para analisá-la; 12) a crítica permeia todo o processo de conhecimento e não 
somente um elemento que põe em questão uma hipótese explicativa. A crítica deve suscitar uma atitude de desconfiança em face do conhecimento como tal; 13) é falsa a separação entre valores científicos e extracientíficos porque os valores são reificados. Os valores também sofrem a cota de reificação ou de coisificação. Nesse caso, os valores não são mais produtos do agir humano, mas sim objetos cristalizados sem ligação com o horizonte humano. A sociologia deve incorporar a consciência de sua antinomia, seu paradoxo e sua contradição; 14) um comportamento isento de valores é impossível psicológica e objetivamente. Não existe independência radical entre a psicologia e a sociologia, sendo a fronteira entre as duas tênue em demasia; 15) a experiência do caráter contraditório da realidade social não é um ponto de partida arbitrário, mas a base da possibilidade da existência da sociologia. Somente os que podem conceber a sociedade de modo diverso do que ela é podem transformá-la em um problema. A desistência da sociologia de uma teoria crítica da sociedade é resignada, não se atreve mais a pensar o todo porque não vê como alterá-lo (Adorno, 1986).

As críticas de Adorno podem ser agrupadas em torno de três grandes temas: quanto ao método e à natureza do objeto, quanto à objetividade científica e quanto à natureza da crítica e da sociologia.

\section{1 - quanto ao método de Popper e à natureza do objeto:}

O método popperiano é uma explicação unívoca, simplificada, diante do objeto sociedade, que é complexo e não unívoco. É nesse ponto que reside a tensão essencial, e não entre conhecimento/ignorância como Popper afirma. A contradição está no objeto sociedade, o que significa para Adorno tratar-se de um problema de caráter prático, e não de um problema de caráter epistemológico.

\section{2 - quanto à objetividade científica:}

Uma possível neutralidade científica em busca da verdade não residiria nem no método nem no cientista. A pretensa objetividade do positivismo purgada de toda projeção subjetiva e o cientista como identificador de problemas significativos não dão conta dessa pretensão equivocada. Ou seja, não existe a possibilidade de julgamentos a priori acerca da relevância dos assuntos nem a separação entre valores científicos e extracientíficos.

\section{3 - quanto à natureza da crítica e da sociologia:}

A crítica permeia todo o processo de conhecimento e não se traduz num elemento que põe em questão uma hipótese explicativa. O método da análise situacional não escapa a esta crítica. A sociologia é crítica do objeto. Se a sociologia pretende que seus conceitos sejam verdadeiros, então ela deve ser crítica com relação à sociedade. 


\section{CONSIDERAÇÕES FINAIS: LIÇÕES DO CONFRONTO}

O objetivo do texto obedeceu à intenção de mostrar como os dois autores estudados, ao longo de suas ricas trajetórias intelectuais, acumularam reflexões e amadureceram argumentos sobre a lógica ou o método mais apropriado para as ciências sociais, tema central do enfrentamento. O texto não traz uma conclusão no sentido estrito do termo, mas uma ideia alusiva de que, para além das posições teórico-analíticas e das perspectivas metodológicas, a visão de mundo presente na obra de Popper e de Adorno contribuiu decisivamente para o esclarecimento dos termos do debate e para o entendimento das raízes filosóficas que estavam em jogo no confronto.

A questão central que orientou o confronto foi a natureza do método, seus limites e potencialidades diante do objeto. Como temas corolários à lógica das ciências sociais foram tratados: a natureza da crítica e questões concernentes à objetividade científica e à totalidade. O ponto de partida da construção teórica de Popper é a sua crítica à razão do homem moderno, cuja matriz está na razão cartesiana que, na sua arrogância, vê a verdade. Popper se identifica com uma razão limitada por uma relativa ignorância ante um mundo complexo incapaz de ser desvelado na sua totalidade. Para Popper a totalidade é algo inacessível, mitológico e a postura humilde do reconhecimento da ignorância somada a uma sagaz crítica ao indutivismo ingênuo constituíram-se no porto seguro para que ele pudesse instituir o critério de falseabilidade, sua marca metodológica.

Contra uma razão totalizadora perante uma realidade complexa inalcançável na sua totalidade, Popper sugere uma razão fragmentada com verdades provisórias, as únicas possíveis. Num momento em que verdades absolutas caem por terra, e que o consagrado está sob suspeita, uma dose de ceticismo e de relativismo tem o apelo de algo afinado com o seu tempo. E é nesse quadro que a proposta de uma razão limitada surge como bom-senso metodológico. Entretanto, guardada a sua contribuição de colocar as verdades absolutas em xeque, há que apontar as limitações de sua razão crítica posto que circunscrita ao plano da lógica formal. O que Popper advoga, em última análise, com o seu método dedutivo da prova, é uma correção da razão cartesiana: ao método hipotético dedutivo acrescentou uma prova, como o próprio nome indica. A essa prova, que tanto pode ser lógica como contrastada com a empiria, chama-se capacidade crítica.

Independentemente da solução metodológica apresentada por qualquer corrente do pensamento, há algo de complexo e estrutural na tarefa dos cientistas sociais, localizado na tensão entre o objeto social a ser compreendido e as limitações de caráter metodológico. A esse ponto central Adorno responde com eloquência. Como traduzir para o plano lógico formal antagonismos reais que não ficam visíveis no interior do sistema lógico-cientificista do pensamento? Como lhe dar uma explicação unívoca, simplificada ao máximo, matematicamente elegante, se o objeto "sociedade" não é unívoco, nem simples? Para Adorno a tensão em Popper está localizada na complexidade do objeto a ser compreendido ante a um método inapropriado. Além disso, a crítica popperiana está circunscrita à crítica interna 
das proposições, constatações sem contradições submetidas às regras da lógica dedutiva. Constructos sem contradições lógicas, nos diz Adorno, não resistem à reflexão de conteúdo porque o que existe, e que é incontornável e contundente, é uma situação problemática do mundo e não um problema de caráter meramente epistemológico. Para Adorno, a perspectiva popperiana se atrofia ao tornar os problemas falsificáveis. Isso significa, em última instância, abstrair-se do objeto e não conseguir interpretar o que afinal de contas, para o campo da dialética, significa perceber a totalidade nos traços dos dados sociais.

Será dentro dessa ideia de algo possível, aproximado ao real, que residirá a tentativa popperiana de dar conta do ambiente social através do seu método da análise situacional. Nessa tentativa reside também um dos seus argumentos centrais para se desvencilhar da pecha positivista, na sua defesa (nos seus primeiros escritos) de um método único para as ciências. ${ }^{7}$ Popper nos apresenta um princípio de racionalidade e uma posição em que o homem age de acordo com a situação dada. Independentemente da crítica que Caldwell fará posteriormente em relação à blindagem do princípio da racionalidade, um princípio que para ele é metafísico, posto que não falsificável nem verificável (Caldwell, 1998), Adorno trata de outra questão. Para Adorno, o método da análise situacional não diverge em essência do método hipotético-dedutivo da prova, cujo critério central é o princípio falsificacionista. De nada vale o argumento popperiano de que não será o princípio da racionalidade que será testado, mas o modelo de análise situacional. O que para Adorno interessa combater é a ideia de que essa lógica das ciências sociais (e da economia como exemplar) oferece a melhor aproximação possível do real. Não, essa lógica não é a melhor possível para as ciências sociais nem o critério de aproximação é o melhor critério para a inteligibilidade dos fenômenos coletivos. Adorno questiona esse artifício de aproximação ao real, aliás, uma ideia central da metodologia neoclássica que, partindo do simples, do ideal, e por aproximações sucessivas, pretende restaurar a complexidade ou se aproximar do real. Essa perspectiva, para Adorno, além de desconsiderar a sociedade como um objeto complexo, inteligível, abstrato, supõe que o princípio da racionalidade dos agentes tem um caráter mais concreto do que as coletividades, as instituições ou a totalidade. Isso significa uma negação da realidade dos fenômenos coletivos e a expressão da desistência de uma teoria crítica da sociedade que não se atreve mais a pensar o todo porque não vê como alterá-lo, satisfazendo-se com fragmentos. Adorno acentua as diferenças de perspectiva e de métodos em que ambos constroem suas teorias e avisa que enquanto a preocupação de Popper é formal, a da dialética é material e emancipatória. Caminhar por essa diferença nos remete a um dos objetivos do

\footnotetext{
${ }^{7}$ Popper afirma que não é um positivista e que isto é um rótulo grosseiro. Positivista é, segundo Popper, aquele para o qual o método das várias ciências é tomado de forma absoluta como o único método do conhecimento. Afirma que sempre lutou a favor das teorias especulativas, contra o cientificismo e contra o empirismo sensualista, considerando a análise positivista inadequada até para as ciências naturais (Popper, 1978).
} 
trabalho, que é chamar para o jogo dessas ideias em confronto a visão de mundo de cada um dos autores.

Embora as visões de mundo dos autores não tenham ficado explícitas no debate, fato que decepcionou alguns comentadores do congresso, ${ }^{8}$ elas estão subjacentes às questões mais contundentes e aos impasses teóricos incontornáveis presentes no coração do debate. Aliás, o medo de se infectar com os argumentos considerados "pré-científicos" parece ter tomado conta dos economistas, sem distinção de filiação teórica, e tem se traduzido numa visão positivista e asséptica das ciências sociais e da economia em particular. Alguns porque se consideram acima de qualquer perspectiva e visão de mundo que os condicione, outros porque pensam que ela só existe nos seus opositores e, a maioria, porque encarnou das mais diversas formas a ideia de que a ciência econômica é neutra e de que unicamente o analítico é válido como ciência, ou é passível de ser isolado. Um exemplo constatado na literatura e nos debates são as preleções ad nauseam sobre a importância da pureza e da validade científica das controvérsias analíticas, a visão shumpeteriana da história da análise econômica. Outro exemplo são as leituras fragmentadas dos pensadores, retirando-lhes de suas histórias e abstraindo-se propositadamente de suas visões de mundo e/ou de suas propostas político-normativas. Esses exemplos comprovam que o positivismo fez e ainda faz muitos adeptos entre nós.

Numa perspectiva oposta, nosso texto foi escrito com o sentido de mostrar que a visão de mundo não só faz parte integrante das humanidades desses autores, como guarda uma imbricada relação com suas teorias e ainda se traduz no centro vivo e interessante do jogo de suas ideias, sobretudo quando postas em confronto. Sem essa visão de mundo não apenas a insipidez subjaz, como dificuldades se apresentam para a exata compreensão dos argumentos em disputa. A visão de mundo veículo discreto, porém presente na arte de convencer o auditório universal. Para nós, a visão de mundo de Popper está intimamente ligada à natureza do seu racionalismo crítico, do mesmo modo que a defesa de uma razão crítica emancipatória faz parte integrante do método dialético de Adorno e da sua participação na construção da teoria crítica e da construção da Escola de Frankfurt. As visões de mundo desses autores pertencem a matrizes filosóficas e ideológicas presentes nas suas teorias e são partes integrantes de suas vidas. Popper não escondeu suas posições político-ideológicas no conturbado século em que viveu, dedicando parte de sua obra e energia a criticar a "miséria do historicismo" e o "falso mundo profético marxista". Além disso, o grande erro que ele constatou em Marx serviu-lhe para construir seu argumento teórico e político. Ao apontar o erro de Marx na sua tentativa de descobrir leis intrínsecas do capitalismo e delas inferir a profecia socialista, seu objetivo ficava cada vez mais claro e isso se constata na leitura de suas

\footnotetext{
${ }^{8}$ Ralf Dahendorf, organizador do debate e do livro sobre o debate, afirma que os assuntos foram tratados como uma certa ironia de concordâncias, mas que no fundo existiam diferenças profundas entre os dois. Aliás, as diferenças de argumentação são tão profundas que é preciso duvidar de que Popper e Adorno são capazes de concordar quanto a um único procedimento (Dahendorf, 1973).
} 
obras. Primeiro, tentando desmontar a possibilidade de encontrar leis gerais unívocas para a história, desacreditando o socialismo e, segundo, substituindo o socialismo científico de Marx por um reformismo, ideal que ele considerava mais modesto e mais viável de se atingir numa sociedade democrática liberal. A crítica à capacidade da razão em desvelar a totalidade e dela inferir leis inexoráveis é própria à onipotência da razão moderna, cuja matriz é Descartes, mas que para Popper se apresenta metamorfoseada com argumentos da materialidade na perspectiva da leitura da história de Marx. Também para o autor, a perspectiva marxista no campo político-normativo em que a história se moveria de forma conflitiva, mas inexorável, retira as possibilidades de se alterar a realidade através de reformismos sucessivos. O marxismo inviabilizaria toda a engenharia social, afirma Popper, ou seja, as possibilidades de se reformar o capitalismo e de se chegar através de reformas (fragmentadas), e de maneira aproximada, a uma sociedade mais justa. Não, dirá ele, à utopia de um mundo inalcançável e, sim, ao que ele considera o viável no reino das possibilidades. É nesse quadro de reformas e concertos do capitalismo que a analogia com a crítica ao método dedutivo ou uma correção epistemológica se faz viável e se expressa como a melhor forma de lidar com uma aproximação à verdade.

Do outro lado temos Adorno, prestigiado representante da Escola de Frankfurt, e sua defesa de uma razão crítica emancipatória. Adorno sustentou junto com seus companheiros da Escola o revigoramento do marxismo na Alemanha e no exílio, munido de uma arguta crítica às expressões contemporâneas do totalitarismo sob todas as suas formas. Aliado a isso, apresentou uma percepção original sobre as novas expressões de dominação e de resistência das consciências manipuladas pela ideologia da indústria cultural. Construiu uma crítica ao positivismo com base na perspectiva da "teoria crítica" e na dialética negativa. Em que pese sua postura crítica com relação ao mecanicismo da perspectiva da lógica da luta de classes e a descrença quanto ao papel da classe operária como parteira da história, seu caminho foi o do marxismo. $\mathrm{Na}$ esteira da dialética negativa construiu um método crítico capaz de enfrentar os inúmeros desafios teóricos ditados pela hegemonia do pensamento positivista, pelo idealismo hegeliano e pelas dificuldades do marxismo ortodoxo em dar conta dos problemas teóricos e políticos do século XX. A dialética, na sua perspectiva, teria a incumbência de ser uma reflexão filosófica sobre aquilo que os conceitos e as análises não dão conta, isto é, um pensar ousado sobre exatamente o que lhe escapa, a única saída para se pensar filosoficamente. Mas esse seu pensar é crítico com relação ao objeto e respeita as suas contradições. Considera o que permaneceu fora do conceito, o que lhe escapa, mostrando sem vergonha a sua insuficiência. E é nessa insuficiência, nas dificuldades de compreensão dos novos desafios que a realidade impõe, que Adorno constrói a sua crítica ligada a um processo de emancipação. Ele toma como exemplo as minorias excluídas (aquelas que carregam a dor e a força) e que se traduzem num desafio teórico e político, posto que se constituem no elo dinâmico que articula a teoria com as possibilidades emancipatórias. Nada mais coerente e articulado, teoria, política e 
ideologia. E nada também tão diferente da teoria, da visão e das propostas políticas de Popper.

O debate tinha como ponto focal tratar a lógica das ciências sociais através de uma disputa pelo melhor método para a explicação de fenômenos coletivos. Partindo de pressupostos e filiações filosóficas distintas, o confronto tornou-se conhecido como a oposição entre o positivismo e a dialética. A ideia de oposição ou de confronto que marcou desde o início o tom do debate mostrava que o caminho para um consenso na solução das controvérsias estava fora de cogitação. Não se tratava de divergências teóricas que poderiam ser solucionadas através de uma conversação civilizada na busca de uma verdade plausível. Isso sempre soou quimérico ou acaciano, sobretudo para os organizadores do debate. Tratava-se de um confronto em que matrizes do pensamento disputavam, diante do auditório universal, o melhor entendimento para os fenômenos sociais. $O$ fato de as questões apresentadas despertarem ainda hoje um permanente interesse na academia parece nos mostrar que as ideias avançam no dissenso e sobretudo quando as divergências são enfrentadas em disputas corajosas.

As ideias apresentadas no confronto continuam alimentando estudos de adeptos e críticos acerca da proposta do método da análise situacional apresentada por Popper no debate. Ainda sobrevive a questão, embora em pequenos círculos, se afinal ele é ou não um positivista. A perspectiva adorniana da teoria crítica permanece como uma releitura viva e provocadora do marxismo, não assimilada pelo marxismo ortodoxo. A teoria crítica da Escola de Frankfurt deixou suas marcas em inúmeros programas de pesquisa filosóficos abertos no século XX. Legou questões para o pensamento crítico acerca das limitações do método hipotético-dedutivo e sublinhou mais uma vez a tensão existente entre o objeto complexo da sociedade a ser compreendido e o método (ou os métodos) mais adequado(s) e profícuo(s) para lidar com ele. Um assunto permanente e, certamente, o maior desafio para as ciências sociais. Uma questão candente que ainda vai suscitar possíveis consensos e inevitáveis confrontos.

\section{REFERÊNCIAS BIBLIOGRÁFICAS}

ADORNO, T., HORKHEIMER, M. (1985[1944]) Dialética do Esclarecimento: Fragmentos Filosóficos. Rio de Janeiro: Jorge Zahar. Tradução de Guido Antonio de Almeida do original alemão: Dialektik der Aufklãrung, Frankfurt, Fisher Verlag.

ADORNO. T. (1986) "Sobre a lógica das ciências sociais”, in Gabriel Cohn, (org.), Theodor W. Adorno. Coleção Grandes Cientistas Sociais. São Paulo: Ática.

. (2009 [1969]) Dialética Negativa, Rio de Janeiro: Jorge Zahar. Tradução de Marco Antonio Casanova, Negative Dialetik $2^{a}$ edição, Frankfurt, Suhrkamp Verlag.

.(1975 [1974]) "Introdução à controvérsia sobre o positivismo na sociologia alemã", in T. Adorno et al., Textos Escolhidos, Coleção Os Pensadores. São Paulo: Abril Cultural.Tradução de Wolfgang Leo Maar, do original alemão Der Positivismusstreit in der deutschen Soziologie, Darmstad und Neuwied, H. Lucterhand Verlag, $3^{\mathrm{a}}$ ed.

CALDWELL, B. (1998) "Situation analyses", in Maki, U. et al (org.), The Handbook of Economic Methodology, USA: E. Elgar. 
DAHENDORF, R. (1973) "Anotaciones a la discussion de las ponencias de Karl R.Popper y Theodor W. Adorno", in Dahendorf, R. (ed.) La Disputa del Positivismo a la Sociologia Alemana. Tradução de Jacob Munoz, Barcelona-Mexico: Grijalbo.

BODEI, R. (2000) A Filosofia do Século XX. Tradução de Modesto Florenzano, São Paulo: EDUSC.

HACOHEN, M.H. (2000) Karl Popper - The Formative Years, 1902-1945 - Politics and Philosophy in Interwar Vienna. Cambridge: Cambridge University Press.

HAYEK, F.A. (1985) La Route de la Servitude. Paris: Quadrige/Presses Universitaires de France. Traduçao de G. Blumberg.

POPPER, K.R. (1989 [1959]) A Lógica da Pesquisa Científica. São Paulo: Editora Cultrix. Tradução de Leonidas Hegenberg e Octanny Silveira da Mota de Logik der Forschung, Tubingen. . (1956 [1944]) Misère de L'Historicisme. Paris: Libraire Plon, 1956. Tradução de Hervé Rousseau, The Poverty of Historicism, Revista Econômica, 1944-1945.

. (1978) "Lógica das ciências sociais", in Lógica das Ciências Sociais. Brasília: Editora Universidade de Brasília. Tradução de Estevão de Rezende Martins et al.

. (1978) “Razão ou revolução?”, in Lógica das Ciências Sociais. Brasília: Editora Universidade de Brasília. Tradução de Estevão de Rezende Martins et al.

. (1979) La Societé Ouverte et ses Ennemis. Paris: Éditions du Seuil. Tradução do inglês por Jacqueline Bernard e Phiplipe Monod.

. (1995a) "La autonomia de la sociologia", in Miller, David (org.), Popper Escritos Selectos. México: Fondo de Cultura Econômica. Tradução de Sergio René Madero Báez.

.(1995b) "El principio de racionalidad”, in Miller, David (org.), Popper Escritos Selectos. México:

Fondo de Cultura Econômica. Tradução de Sergio René Madero Báez. 